\title{
ORGANIZATIONAL FICTION OF AN EDUCATIONAL INSTITUTION IN BUILDING ORGANIC LEADERSHIP - A CASE STUDY
}

\author{
ANNA HESSE-GAWĘDA \\ Jagiellonian University, Faculty of Management and Social, POLAND \\ e-mail: ania.hg48@gmail.com
}

RECEIVED
ACCEPTED
JEL
CLASSIFICATION

KEYWORDS

ABSTRACT

\author{
14 July 2017 \\ 15 December 2017 \\ 121,128
}

organizational fiction, educational leadership, leadership styles

This article discusses organizational fiction that is created in building a participative work environment. The statement in which the school head declares full cooperation with the teachers, considering their opinions and creating the conditions for common planning does not translate into the results of the research among the teachers. A significant difference in particular actions taken on everyday basis can be noticed. The author discusses the four styles of leadership proposed by Gayle Avery and highlights the role of organic leadership for a well-functioning educational institution in the era of changes and reforms that are introduced in education. The article was written on the basis of the results of the research that was carried out in a randomly selected public Primary School. The author aims at drawing attention to and starting a critical discussion on actions taken by school heads who create an external image of their school that differs from the reality. It leads to manipulating the public opinion about the processes occurring in a given educational institution.

\section{Introduction}

The Polish management professionals in education undergo constant transformation due to the reforms that are being introduced. It is the result of the growing self-awareness of the society and of the introduced systemic changes. The new conditions in which school heads operate allow for more flexibility and encourage them to share their power. What reinforces the ongoing process of searching for the leader of the future is the reform of 
pedagogical supervision introduced in 2009 that, in a way, directs school heads to apply the participative style of leadership, consisting in including all people that make up the school community in enhancing the quality of learning processes. In order to meet the state's requirements as to the right functioning of educational institutions, it is necessary to look at the styles of leadership represented by school heads.

Gayle Avery (2004) proposed four models of leadership: classical (the school head has absolute power), transactional (the school head discusses some issues with the teachers but he or she has the last word), visionary (the school head has a particular vision and the teachers have to follow it) and organic (all members of the organization are responsible for achieving the established goals and the leader emerges from the group according to the needs). Those style permeate one another and can be complimentary, which does not alter the fact that organic leadership is the most desirable way of leading an organization in the ever-changing reality. The confirmation of this thesis can be found in the conception of a discreet leader proposed by Mintzberg (1998) that, in contemporary management, makes an organization develop faster. Creating teams and groups made up by experts and sharing power make all members of an organization feel that they belong in it and are responsible for the processes occurring in it.

\section{Litepature review}

An organization is a coherent system in which changes of one element entail other changes. A system cannot be completely independent as it would not be a system then. This is why we can only speak of a degree of independence (Kieżun, 1997). The most important role is played here by the leader of a given organization, who directly influences the fulfilment of given goals. His or her actions can lead to blurring the truth and creating a fictitious image. Fiction created in an organization is then nothing but organizational pathology. It undoubtedly becomes an obstacle in achieving organizational efficiency (Kieżun, 1997). This phenomenon can be noticed in organizations where the system imposes some norms of functioning. The willingness to meet the requirements as well as possible oftentimes makes school heads engage in inappropriate actions that have a negative impact on the institution's functioning. Referring to Avery (2004), it is worth reminding that organic leadership allows for blurring the formal distinction between leaders and other members of the organization. All employees become partners in creating a better future. Leadership becomes dispersed and the knowledge of employees grows. Members of the organization are always prepared for changes on both small and large scale, which fully corresponds with the surrounding reality. All individuals that make up the organization's community develop a sense of responsibility towards themselves. It results from their personal involvement in pursuing the established goals and from their sense of duty towards the others.

Educational management is a relatively new discipline in Poland. Applying a simple transfer of methods from the general management sciences, which has dominated since 1980s, can have some impact on creating organizational fiction in educational institutions. The managerial theory focused on financial, technical, organizational and legal requirements sees success as efficiency in education functioning (Dorczak, 2016). All this oftentimes results in forgetting the real role that school has to perform for children and adolescents that attend it. It is then worth reminding that the overriding and basic role of each educational institution is to create an organization oriented towards students' learning and their development (Hattie, 2012). 


\section{Method}

Every head of an educational institution follows a certain leadership style in his or her professional work. It is commonly accepted that the most appropriate style is the organic one, which includes all members in creating a common organization. To study leadership style, we have appointed the head of a randomly selected Primary School and eleven randomly selected teachers who teach in the same school as the interviewed leader. The aim was to compare what the school head says about himself and how his actions are perceived by the teachers. It should be assumed that the school head's statements would be coherent with the teachers' statements.

\section{Resullts}

The respondents were asked to fill in the questionnaire of the survey containing 15 closed questions prepared for the purposes of this research. The questions concerned key characteristics of a leader, the main role that he or she should perform in an educational institution and ways of sharing power. In the gathered material, there are 15 answers from the school head and 165 answers from the teachers. The results of the research present the leadership style represented by the head of the primary school (Table 1) in subjective opinions of the respondents.

Table 1. Leadership style represented by the school head in the opinions of the surveyed school head and the teachers who work with him (\%)

\begin{tabular}{|l|c|c|c|c|}
\hline \multicolumn{1}{|c|}{$\begin{array}{c}\text { Surveyed respondents } \\
\text { and their opinions }\end{array}$} & Classical leadership & Transactional leadership & Visionary leadership & Organic leadership \\
\hline School head & 13.33 & 20.00 & 13.33 & $\mathbf{5 3 . 0 0}$ \\
\hline Teachers & 49.69 & 24.24 & 7.27 & 18.78 \\
\hline
\end{tabular}

Source: own elaboration.

Analysing the result of the survey, we can note that the school head perceives his actions taken for the institution as organic leadership, while the teachers who work with him every day state quite the opposite. In $49.69 \%$ they state that the leadership style of their school head is classical. The reason for this situation may be that the school head idealizes himself and lacks the ability to rationally look into his own activity.

The tables below present the detailed results of the survey gathered from the school head and his employees.

Table 2. Answers given by the school head and the teachers to question 1.

\begin{tabular}{|c|c|c|c|c|}
\hline \multirow[t]{2}{*}{ Possible answers } & \multicolumn{2}{|c|}{$\begin{array}{c}\text { School head } \\
\text { What key characteristics should } \\
\text { a leader have? }\end{array}$} & \multicolumn{2}{|c|}{$\begin{array}{c}\text { Teachers } \\
\text { What key characteristics does your } \\
\text { present school head have? }\end{array}$} \\
\hline & $\mathrm{n}$ & $\%$ & $\mathrm{n}$ & $\%$ \\
\hline Strong character, firm, decided, opinionated & 0 & 0 & 6 & 54.54 \\
\hline Communicative, able to influence people & 0 & 0 & 5 & 45.45 \\
\hline Creative, unconventional, seeking for new solutions, inspiring & 0 & 0 & 0 & 0 \\
\hline Open, knows the people, stimulating others to act, supportive & 1 & 100.00 & 0 & 0 \\
\hline Total & 1 & 100.00 & 11 & 100.00 \\
\hline
\end{tabular}

Source: own elaboration. 
From the data presented above we can conclude that the school head sees himself as an open person who knows very well the people he works with and gladly stimulates them to act supporting all ideas. The teachers have a different opinion as they say that their employer is firm and decided, has a strong character and hold stubbornly to his own opinions. This result presents organizational fiction that can induce chaos in the right way of functioning of an educational institution.

Table 3. Answers given by the school head and the teachers to question 2.

\begin{tabular}{lcccc}
\hline \multirow{2}{*}{ Possible answers } & \multicolumn{2}{c}{$\begin{array}{c}\text { School head } \\
\text { What should be the main role performed by a leader? }\end{array}$} & $\begin{array}{c}\text { Teachers } \\
\text { What is the main role performed by the head of the school } \\
\text { that you work in? }\end{array}$ \\
\cline { 2 - 5 } & $\mathrm{n}$ & $\%$ & $\mathrm{n}$ & $\%$ \\
\hline Decisive & 1 & 100.00 & 1 & 81.81 \\
Negotiator & 0 & 0 & 1 & 9.09 \\
Creator & 0 & 0 & 0 & 9.09 \\
Supporting others & 0 & 0 & 11 & 0 \\
\hline Total & 1 & 100.00 & 100.00 \\
\hline
\end{tabular}

Source: own elaboration.

The results obtained in the second question show unanimity among the teachers and the school head. Most of them agree that the present school head is the one who has the casting vote. This result goes along with classical leadership where strict obedience plays the most important role in creating the organization.

Table 4. Answers given by the school head and the teachers to question 3.

\begin{tabular}{|c|c|c|c|c|}
\hline \multirow[t]{2}{*}{ Possible answers } & \multicolumn{2}{|c|}{$\begin{array}{c}\text { School head } \\
\text { What main tasks/action should the } \\
\text { leader perform? }\end{array}$} & \multicolumn{2}{|c|}{$\begin{array}{c}\text { Teachers } \\
\text { What main tasks/action does } \\
\text { the present head of your school } \\
\text { perform? }\end{array}$} \\
\hline & $\mathrm{n}$ & $\%$ & $\mathrm{n}$ & $\%$ \\
\hline Making sure that everybody acts according to the assigned duties & 0 & 0 & 8 & 72.72 \\
\hline Communicating with people and negotiating on the directions of action & 0 & 0 & 2 & 18.18 \\
\hline Searching for new solutions & 0 & 0 & 0 & 0 \\
\hline Creating conditions for operation and development for people and teams & 1 & 100.00 & 1 & 9.09 \\
\hline Total & 1 & 100.00 & 11 & 100.00 \\
\hline
\end{tabular}

Source: own elaboration.

Analysing the results obtained in question 3, we can notice another significant difference in the perception of the school head's role. Most of the teachers $-72.72 \%$ believe that their school head makes sure that each of them acts according to the assigned tasks, which translates into classical leadership style. Whereas, the school head believes quite the opposite. He is convinced that he creates friendly conditions for his employees to act and develop, which serves organic leadership. 
Table 5. Answers given by the school head and the teachers to question 4.

\begin{tabular}{|c|c|c|c|c|}
\hline \multirow{3}{*}{ Possible answers } & \multirow{2}{*}{\multicolumn{2}{|c|}{$\begin{array}{l}\text { School head } \\
\text { How, as the school head, } \\
\text { do you distribute tasks? }\end{array}$}} & \multirow{2}{*}{\multicolumn{2}{|c|}{$\begin{array}{c}\text { Teachers } \\
\text { How does the school head } \\
\text { distribute tasks? }\end{array}$}} \\
\hline & & & & \\
\hline & $\mathrm{n}$ & $\%$ & $\mathrm{n}$ & $\%$ \\
\hline The school head assigns tasks & 0 & 0 & 6 & 54.54 \\
\hline The school head negotiates task distribution & 0 & 0 & 3 & 27.27 \\
\hline The school head inspires others and makes them follow his ideas & 1 & 100.00 & 1 & 9.09 \\
\hline The school head gives the opportunity for others to find themselves and choose their tasks & 0 & 0 & 1 & 9.09 \\
\hline Total & 1 & 100.00 & 11 & 100.00 \\
\hline
\end{tabular}

Source: own elaboration.

The results from question 4 confirm the classical leadership style, with which the school head disagrees. He believes that he inspires others and makes them follow his ideas. That kind of actions characterizes visionary leadership.

Table 6 . Answers given by the school head and the teachers to question 5 .

\begin{tabular}{|c|c|c|c|c|}
\hline \multirow{3}{*}{ Possible answers } & \multirow{2}{*}{\multicolumn{2}{|c|}{$\begin{array}{l}\text { School head } \\
\text { What strategy do you, as the } \\
\text { school head, apply while setting } \\
\text { goals and planning work? }\end{array}$}} & \multirow{2}{*}{\multicolumn{2}{|c|}{$\begin{array}{l}\text { Teachers } \\
\text { What strategy does the school } \\
\text { head apply while setting goals } \\
\text { and planning work? }\end{array}$}} \\
\hline & & & & \\
\hline & $\mathrm{n}$ & $\%$ & $\mathrm{n}$ & $\%$ \\
\hline The school head precisely sets the goals and the plan of action & 0 & 0 & 6 & 54.54 \\
\hline Goals and a detailed plan are set commonly through negotiations & 0 & 0 & 2 & 18.18 \\
\hline The school headsets creative goals and plans that are attractive for others & 0 & 0 & 0 & 0 \\
\hline $\begin{array}{l}\text { The school head creates the conditions for everybody to influence their goals } \\
\text { and work plans }\end{array}$ & 1 & 100.00 & 3 & 27.27 \\
\hline Total & 1 & 100.00 & 11 & 100.00 \\
\hline
\end{tabular}

Source: own elaboration.

The answers presented in question 5 show contradictory interpretations of the school head's actions, which causes the creation of organizational fiction. The school head is convinced that every employee has the opportunity to influence the goals and plans of the institutions. Most of the teachers $-54.54 \%$ believe the opposite though. They say that the school headsets the goals and plans of action, which undoubtedly is characteristic for classical leadership.

The results of the survey presented in Table 7 again show some discrepancy between what the school head declares and what the teachers believe. The school's leader claims that he builds the team basing on his knowledge of his employees and their strengths and weaknesses, whereas $72.72 \%$ of the surveyed teachers say that the school head appoints teachers to given tasks or teams himself. Yet again we can notice here some elements that may create organizational fiction. 
Tahle 7. Answers given by the school head and the teachers to question 6 .

\begin{tabular}{|c|c|c|c|c|}
\hline \multirow[t]{2}{*}{ Possible answers } & \multicolumn{2}{|c|}{$\begin{array}{c}\text { School head } \\
\text { What processes should occur } \\
\text { in school while building a team } \\
\text { and assigning tasks to its members? }\end{array}$} & \multicolumn{2}{|c|}{$\begin{array}{c}\text { Teachers } \\
\text { What processes do occur in school } \\
\text { while building a team and assigning } \\
\text { tasks to its members? }\end{array}$} \\
\hline & $\mathrm{n}$ & $\%$ & $\mathrm{n}$ & $\%$ \\
\hline The school head appoints people to the team and assigns tasks to them & 0 & 0 & 8 & 72.72 \\
\hline $\begin{array}{l}\text { Teams membership and tasks distribution is agreed on through } \\
\text { negotiations }\end{array}$ & 0 & 0 & 1 & 9.09 \\
\hline $\begin{array}{l}\text { The teams and task distribution are set spontaneously, following the } \\
\text { school head's ideas }\end{array}$ & 0 & 0 & 0 & 0 \\
\hline $\begin{array}{l}\text { The teams are created basing on the knowledge of people and their } \\
\text { strengths/weaknesses }\end{array}$ & 1 & 100.00 & 2 & 18.18 \\
\hline Total & 1 & 100.00 & 11 & 100.00 \\
\hline
\end{tabular}

Source: own elaboration.

Table 8. Answers given by the school head and the teachers to question 7.

\begin{tabular}{|c|c|c|c|c|}
\hline \multirow[t]{2}{*}{ Possible answers } & \multicolumn{2}{|c|}{$\begin{array}{l}\text { School head } \\
\text { What methods of work } \\
\text { are appreciated the most? }\end{array}$} & \multicolumn{2}{|c|}{$\begin{array}{l}\text { Teachers } \\
\text { What methods of work } \\
\text { are appreciated the most in the } \\
\text { school that you work in? }\end{array}$} \\
\hline & $\mathrm{n}$ & $\%$ & $\mathrm{n}$ & $\%$ \\
\hline Individual work & 0 & 0 & 2 & 18.18 \\
\hline Team work with clearly established tasks and responsibilities & 0 & 0 & 3 & 27.27 \\
\hline Various, according to ideas and the needs of the moment & 1 & 0 & 5 & 45.45 \\
\hline Adapted to the needs of the moment and to people's predispositions & 0 & 100.00 & 1 & 9.09 \\
\hline Total & 1 & 100.00 & 11 & 100.00 \\
\hline
\end{tabular}

Source: own elaboration.

The obtained information on methods of work show agreement between the teachers and the school head. They all referred to visionary leadership style, in which the school head appreciated various methods and techniques of work according to ideas and the needs of the moment.

Table 9. Answers given by the school head and the teachers to question 8 .

\begin{tabular}{|c|c|c|c|c|}
\hline \multirow{3}{*}{ Possible answers } & \multirow{2}{*}{\multicolumn{2}{|c|}{$\begin{array}{l}\text { School head } \\
\text { What are the sources of the leader's } \\
\text { authority? }\end{array}$}} & \multirow{2}{*}{\multicolumn{2}{|c|}{$\begin{array}{c}\text { Teachers } \\
\text { What are the sources of authority } \\
\text { of the head of your school? }\end{array}$}} \\
\hline & & & & \\
\hline & $\mathrm{n}$ & $\%$ & $\mathrm{n}$ & $\%$ \\
\hline The school head's formal position & 0 & 0 & 7 & 63.63 \\
\hline The school head's high level of interpersonal abilities & 0 & 0 & 1 & 9.09 \\
\hline The school head's creative mind & 0 & 0 & 1 & 9.09 \\
\hline The school head's ability to form relationships with people & 1 & 100.00 & 2 & 18.18 \\
\hline Total & 1 & 100.00 & 11 & 100.00 \\
\hline
\end{tabular}

Source: own elaboration. 
The data concerning the sources of authority again show some discrepancy creating organizational fiction. The school head claims that he has the ability to form relationships with people. The teachers are of a different opinion. $63.63 \%$ of the respondents claim that the school head has a formal position, which goes along with classical leadership.

Table 10. Answers given by the school head and the teachers to question 9 .

\begin{tabular}{|c|c|c|c|c|}
\hline \multirow[t]{2}{*}{ Possible answers } & \multicolumn{2}{|c|}{$\begin{array}{c}\text { School head } \\
\text { How are decisions made } \\
\text { in the school? }\end{array}$} & \multicolumn{2}{|c|}{$\begin{array}{c}\text { Teachers } \\
\text { How are decisions made } \\
\text { in the school? }\end{array}$} \\
\hline & $\mathrm{n}$ & $\%$ & $\mathrm{n}$ & $\%$ \\
\hline Decisions are always or almost always made by the school head & 0 & 0 & 7 & 63.63 \\
\hline Decisions are made by consensus & 0 & 0 & 2 & 18.18 \\
\hline Decisions are clearly the manifestation of the school head's creative ideas & 0 & 0 & 0 & 0 \\
\hline Decisions are made by those who are responsible for the task & 1 & 100.00 & 2 & 18.18 \\
\hline Total & 1 & 100.00 & 11 & 100.00 \\
\hline
\end{tabular}

Source: own elaboration.

Another example of creating organizational fiction can be found in the results of question 9 . The school head says that decisions are made by those who are responsible for a given task, which characterizes organic leadership. The teachers have a different opinion and $63.63 \%$ of them claim the decisions are always or almost always made by the school head. That way of decision making is typical for classical leadership.

Table 11. Answers given by the school head and the teachers to question 10.

\begin{tabular}{|c|c|c|c|c|}
\hline \multirow{3}{*}{ Possible answers } & \multirow{2}{*}{\multicolumn{2}{|c|}{$\begin{array}{l}\text { School head } \\
\text { What methods are used in the school } \\
\text { in solving conflicts? }\end{array}$}} & \multirow{2}{*}{\multicolumn{2}{|c|}{$\begin{array}{c}\text { Teachers } \\
\text { What methods are used in the school } \\
\text { in solving conflicts? }\end{array}$}} \\
\hline & & & & \\
\hline & $\mathrm{n}$ & $\%$ & $\mathrm{n}$ & $\%$ \\
\hline The school head is the most important institution that solves conflicts & 0 & 0 & 2 & 18.18 \\
\hline Conflicts are solved by negotiations between the sides & 1 & 100.00 & 8 & 72.72 \\
\hline The school head usually has the best ideas for solving conflicts & 0 & 0 & 0 & 0 \\
\hline Conflicts are an occasion to learn & 0 & 0 & 1 & 9.09 \\
\hline Total & 1 & 100.00 & 11 & 100.00 \\
\hline
\end{tabular}

Source: own elaboration.

The data presented in Table 11 shows coherence between the teachers' $(72.72 \%)$ and the school head's opinions concerning the methods used in solving conflicts. The respondents agree in referring to transactional leadership.

The data concerning the strategies applied in difficult situations or crises again shows a significant discrepancy that may contribute to creating organizational fiction. The school head is convinced that all members of the organization contribute to solving the problem. This way of thinking is not reflected in the teachers' opinion. $45.45 \%$ of them believe that in urgencies it is the school head who takes the reins. 
Table 12. Answers given by the school head and the teachers to question 11.

\begin{tabular}{|c|c|c|c|c|}
\hline \multirow{3}{*}{ Possible answers } & \multicolumn{2}{|c|}{ School head } & \multicolumn{2}{|c|}{ Teachers } \\
\hline & \multicolumn{2}{|c|}{$\begin{array}{l}\text { What strategies are applied in the } \\
\text { school in difficult situations or crises? }\end{array}$} & \multicolumn{2}{|c|}{$\begin{array}{l}\text { What strategies are applied in the } \\
\text { school in difficult situations or crises? }\end{array}$} \\
\hline & $\mathrm{n}$ & $\%$ & $\mathrm{n}$ & $\%$ \\
\hline In urgencies the school head takes the reins & 0 & 0 & 5 & 45.45 \\
\hline $\begin{array}{l}\text { In urgencies actions are taken according to the established role } \\
\text { distribution in the school }\end{array}$ & 0 & 0 & 4 & 36.36 \\
\hline The school heads copes with urgencies the best & 0 & 0 & 0 & 0 \\
\hline In urgencies everyone contributes to the solution & 1 & 100.00 & 2 & 18.18 \\
\hline Total & 1 & 100.00 & 11 & 100.00 \\
\hline
\end{tabular}

Source: own elaboration.

Table 13. Answers given by the school head and the teachers to question 12.

\begin{tabular}{|c|c|c|c|c|}
\hline \multirow{3}{*}{ Possible answers } & \multicolumn{2}{|c|}{ School head } & \multicolumn{2}{|c|}{ Teachers } \\
\hline & \multicolumn{2}{|c|}{$\begin{array}{l}\text { How are changes introduced in the } \\
\text { school of which you are the head? }\end{array}$} & \multicolumn{2}{|c|}{$\begin{array}{l}\text { How are changes introduced } \\
\text { in the school in which you work? }\end{array}$} \\
\hline & $\mathrm{n}$ & $\%$ & $\mathrm{n}$ & $\%$ \\
\hline $\begin{array}{l}\text { Ideas for change come from the school head and he decides whe } \\
\text { they are introduced }\end{array}$ & 0 & 0 & 3 & 27.27 \\
\hline Ideas for change are negotiated on in the team & 1 & 100.00 & 4 & 36.36 \\
\hline The school head is usually right in fact & 0 & 0 & 0 & 0 \\
\hline Changes are a constant element of work and team development & 0 & 0 & 4 & 36.36 \\
\hline Total & 1 & 100.00 & 11 & 100.00 \\
\hline
\end{tabular}

Source: own elaboration.

Analysing the answers to question 12 , we can see that the school declares that all ideas for change are negotiated on in the team. The teachers share that opinion and, in addition, claim that changes are a constant element of work and team development. The results indicate that transactional and organic leadership permeate here.

Table 14. Answers given by the school head and the teachers to question 13.

\begin{tabular}{|c|c|c|c|c|}
\hline \multirow[t]{2}{*}{ Possible answers } & \multicolumn{2}{|c|}{$\begin{array}{l}\text { School head } \\
\text { How is the process of information } \\
\text { management organized } \\
\text { in the school? }\end{array}$} & \multicolumn{2}{|c|}{$\begin{array}{c}\text { Teachers } \\
\text { How is the process of information } \\
\text { management organized } \\
\text { in the school? }\end{array}$} \\
\hline & $\mathrm{n}$ & $\%$ & $\mathrm{n}$ & $\%$ \\
\hline The information flow is controlled by the school head & 0 & 0 & 4 & 36.36 \\
\hline $\begin{array}{l}\text { Information is transferred according to the formally established teams } \\
\text { and rules }\end{array}$ & 0 & 0 & 2 & 18.18 \\
\hline The school head informs about his ideas on a regular basis & 0 & 0 & 3 & 27.27 \\
\hline $\begin{array}{l}\text { The school head creates the conditions for everyone to speak their } \\
\text { mind and access information }\end{array}$ & 1 & 100.00 & 2 & 18.18 \\
\hline Total & 1 & 100.00 & 11 & 100.00 \\
\hline
\end{tabular}

Source: own elaboration. 
The obtained information presented in Table 14 again proves that there is some discrepancy between what the school head declares and what the teachers say. $36.36 \%$ of the school's employees indicate that the school head is a classical leader as he controls the information flow. Whereas, the school head sees himself as an organic leader, as he claims that everybody has the opportunity to speak their mind and access information.

Table 15. Answers given by the school head and the teachers to question 14 .

\begin{tabular}{|c|c|c|c|c|}
\hline \multirow[t]{2}{*}{ Possible answers } & $\begin{array}{l}\text { How is the } \\
\text { and its ex }\end{array}$ & $\begin{array}{l}\text { een the school } \\
\text { nt agreed on? }\end{array}$ & \multicolumn{2}{|c|}{$\begin{array}{l}\text { Teachers } \\
\text { How is the cooperation between the school } \\
\text { and its external environment agreed on? }\end{array}$} \\
\hline & $\mathrm{n}$ & $\%$ & $n$ & $\%$ \\
\hline $\begin{array}{l}\text { The school head decides as to with whom the school } \\
\text { cooperates himself }\end{array}$ & 0 & 0 & 2 & 18.18 \\
\hline $\begin{array}{l}\text { The rules of the school's cooperation with external } \\
\text { organizations are clearly established }\end{array}$ & 1 & 100.00 & 0 & 0 \\
\hline $\begin{array}{l}\text { Most often it is the school head who has ideas } \\
\text { concerning how and with whom the school should } \\
\text { cooperate }\end{array}$ & 0 & 0 & 1 & 9.09 \\
\hline $\begin{array}{l}\text { Cooperation is started according to the needs of the } \\
\text { people and the team }\end{array}$ & 0 & 0 & 8 & 72.72 \\
\hline Total & 1 & 100.00 & 11 & 100.00 \\
\hline
\end{tabular}

Source: own elaboration.

The answers obtained in question 14 again demonstrate the lack of coherence. $72.72 \%$ of the teachers believe that the school head starts cooperation with the local environment according to the needs of the people and the team, which indicated organic leadership. The school head sees himself as a transactional leader in that aspect, as he claims that cooperation with the local environment is clearly established.

Tahle 16. Answers given by the school head and the teachers to question 15.

\begin{tabular}{|c|c|c|c|c|}
\hline \multirow{3}{*}{ Possible answers } & \multicolumn{2}{|c|}{ School head } & \multicolumn{2}{|c|}{ Teachers } \\
\hline & \multicolumn{2}{|c|}{$\begin{array}{l}\text { How is work assessment/evaluation } \\
\text { carried out in the school? }\end{array}$} & \multicolumn{2}{|c|}{$\begin{array}{l}\text { How is work assessment/evaluation } \\
\text { carried out in the school? }\end{array}$} \\
\hline & $\mathrm{n}$ & $\%$ & $\mathrm{n}$ & $\%$ \\
\hline The school head assesses others and their actions himself. & 1 & 100.00 & 7 & 63.63 \\
\hline The rules of assessing people and actions are agreed on with the team. & 0 & 0 & 2 & 18.18 \\
\hline Assessment is carried out spontaneously in the course of work. & 0 & 0 & 0 & 0 \\
\hline $\begin{array}{l}\text { The main way of assessing people and their work is their self-assessment } \\
\text { and evaluation of their own work. }\end{array}$ & 0 & 0 & 2 & 18.18 \\
\hline Total & 1 & 100.00 & 11 & 100.00 \\
\hline
\end{tabular}

Source: own elaboration.

Analysing the last question in the survey's questionnaire, we can see that the school head and most of the teachers agree that the leader assesses others himself. That type of action is typical for classical leadership. 
The analysis of the data presented in the tables shows that in five cases the school head's answers were coherent with what the teachers who work in the same school stated. Unfortunately in as many as nine questions the school head did not give the same answer as the teachers (Figure 1).

SCHOOL HEAD'S STATEMENTS

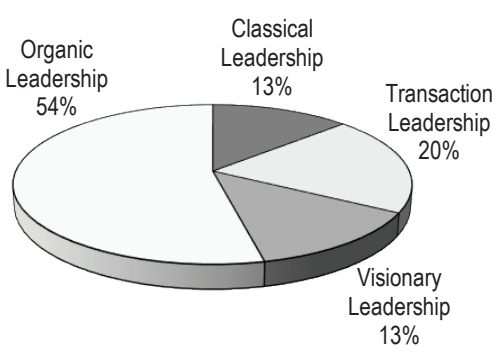

TEACHERS' STATEMENTS

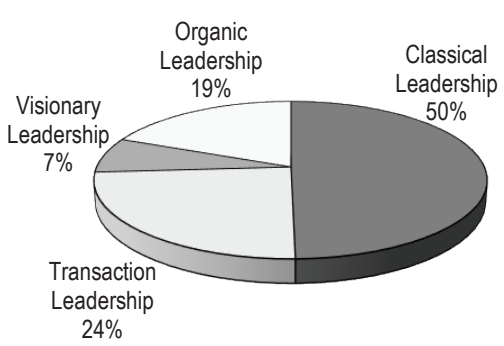

Figur 1. Coherence of statements concerning the same aspect among the school head and the teachers who work in the same educational institution

Source: own elaboration.

\section{Conclusions}

The aim of this study was to present the results of the research concerning creating organizational fiction in building a participative work environment. The material gathered in the research and the conducted analyses show that the head of a randomly selected Primary School who took part in the study in $54 \%$ sees his actions as fostering organic leadership. Only $13 \%$ of his decisions refer to classical leadership. These statements are not reflected in the interviews conducted among teachers. $50 \%$ of the respondents declare that the school head with whom they work organizes his actions within classical leadership paradigm, $24 \%$ believe that transactional leadership is the dominant style, $19 \%$ claim that the school head represents organic leadership and $7 \%$ refer to visionary leadership.

The discrepancies observed in the research may have a negative impact on creating unanimity in pursuing the established goals. Oftentimes it may lead to a struggle between the truth and fiction concerning a given school's functioning. All process that contain contradictions are an impulse for continuous development. Kieżun (1997) points out that complete agreement and unanimity may prove dangerous as they may be a result of passivity. However, it does not alter the fact that the school head should look into his or her actions, bearing in mind that it influences the functioning and involvement of other members who make up the school organization. 


\section{References}

Avery, G. (2004). Understanding Leadership. Paradigms and Cases. Thousand Oaks-New Delhi: Sage Publications.

Dorczak, R. (2016). Sposób rozumienia przez nauczycieli podstawowych wartości edukacyjnych a rzeczywistość współczesnej szkoły. In: R. Dorczak (ed.), Wybrane aspekty zarządzania i przywództwa edukacyjnego (pp. 7-16). Kraków: Wydawnictwo Uniwersytetu Jagiellońskiego.

Hattie, J. (2012). Visible Learning for teachers. Maximizing Impact on Learning. London and New York: Routledge.

Mintzberg, H. (1998). Covert Leadership: Notes on Managing Professionals. Harvard Business Review, 6 (76), 140-147.

Kieżun, W. (1997). Sprawne zarządzanie organizacją. Warszawa: Oficyna Wydawnicza SGH.

Cite this article aS: Hesse-Gawęda, A. (2018). Organizational fiction of an educational institution in building organic leadership - a case study. European Journal of Service Management, 2 (26), 111-121. DOI: 10.18276/ejsm.2018.26-14. 